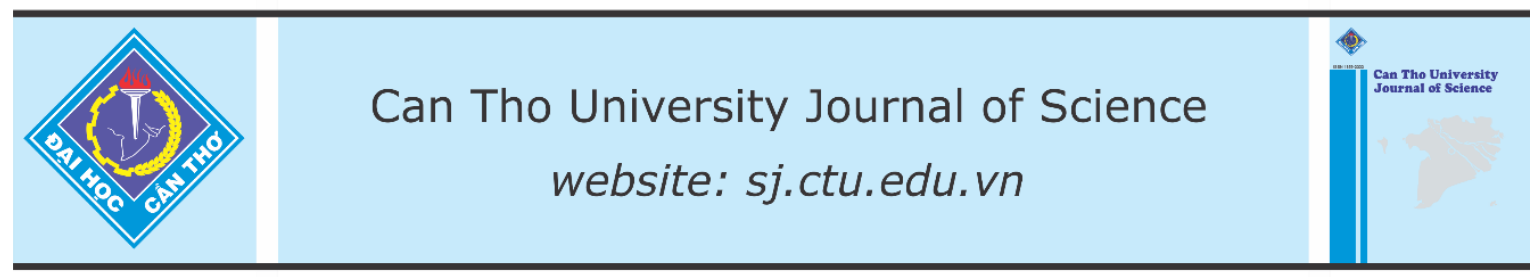

DOI: $10.22144 /$ ctu.jen.2021.003

\title{
Investigation of antioxidant activity of protein hydrolysate derived from baby clam (Corbiculidae sp.) broth
}

Vo Dinh Le Tam*, Tran Cao Minh, Le Duc Hoai, Duong Lap Khang and Nguyen Ngoc Quynh Anh

Division of Food Technology, Faculty of Chemical Engineering, Ho Chi Minh City University of Technology - Vietnam National University, Vietnam

*Correspondence: Vo Dinh Le Tam (email:vdlt@hcmut.edu.vn)

\section{Article info.}

Received 10 Nov 2020

Revised 26 Feb 2021

Accepted 31 Mar 2021

\section{Keywords}

Antioxidant activity, baby clam broth, hydrolysis, protein hydrolysate, proteolysate, proteolysis

\begin{abstract}
This study is aimed to bring baby clam broth $(B C B)$ into antioxidant proteolysate utilizing enzymatic hydrolysis. Chemical compositions of $B C B$ were firstly analyzed, followed by investigating the effects of enzymatic hydrolysis parameters involving in enzyme type, $\mathrm{pH}$, temperature, enzyme:substrate $(E: S)$ ratio and hydrolysis time on antioxidant of $B C B$ proteolysate. It can be seen from the result that the $B C B$ owned the moisture content, protein content, lipid content, and ash content of $97.55 \pm 0.89 \%$, $1.52 \pm 0.16 \%, 0.09 \pm 0.02 \%$, and $0.37 \pm 0.04 \%$, respectively. The BCB proteolysate, under the hydrolysis condition including Flavourzyme, $\mathrm{pH} 7$, $50^{\circ} \mathrm{C}$, E:S ratio of $5 \mathrm{U} / \mathrm{g}$ protein and hydrolysis time of $50 \mathrm{~min}$, exhibited the highest 2,2'-Azino-bis(3-ethylbenzthiazoline-6-sulfonic acid) cation ratio $\left(\right.$ ABTS $\left.^{\bullet+}\right)$ scavenging activity of $770.67 \pm 28.33 \mu \mathrm{M}$ Trolox Equivalent $(\mu M T E)$ (7.1 and 2.5 times lower than those of vitamin $C$ and butylated hydroxytoluene (BHT), in order) and ferric reducing antioxidant power (FRAP) value of $245.26 \pm 7.37 \mu M$ TE (11.6 and 4.0 folds lower than those of vitamin $C$ and BHT, respectively). This study suggests a new use of the $B C B$, antioxidant proteolysate which could be applied as a functional food or natural antioxidant additive, substituting for synthetic compounds.
\end{abstract}

\section{INTRODUCTION}

When antioxidant defense systems fail to protect the body against reactive radicals, oxidative stress which occurs leading to numerous fatal diseases such as cancer, atherosclerosis, diabetes, arthritis, coronary heart disease, and Alzheimer's disease (Wang et al., 2015). Besides, deleteriousness of free radicals is also affected by diminution in shelf life, quality. and safety of food products (Kim \& Wijesekara, 2010). Using antioxidants, which would delay or inhibit oxidation of a substance, could prevent these negative effects. Even though synthetic antioxidants including butylated hydroxyanisole (BHA), butylated hydroxytoluene (BHT), tbutylhydroquinone (TBHQ) and propyl gallate (PG) are cost-effective as well as exert high antioxidant potential, they display several hazardous effects. As a result, their use was restricted in some countries (Zhang et al., 2012). Recently, safe and natural antioxidants have caught many scientists' attention. It was reported from Kim and Wijesekara (2010) that peptides from aquatic products and their by-products, due to the interruption of lipid peroxidation, exert the scavenging capability of free radicals and reactive oxygen species or prevent oxidative damage. The findings of Sarmadi and Ismail (2010) showed that antioxidative peptides, specific protein fragments that could be released by enzymatic hydrolysis are considered to be safe, healthy, and easy to be absorbed. 
Baby clam is an aquatic life form with low economic value, and its fresh form is consumed in a large amount, particularly in Hue with the iconic dish of baby clam rice. In this case, huge quantity of its broth is directly disposed of into the environment. Therefore, this study's aim is to produce bioactive proteolysate, especially antioxidant proteolysate from its waste. So far, there is hardly any publications on bioactive proteolysate from the BCB.

In this study, two different mechanisms involving in electron transfer capacity and hydrogen atom transfer capacity were employed to examine the antioxidant activity of the BCB proteolysate. Evaluation of electron donating capability of $\mathrm{BCB}$ proteolysate was done utilizing FRAP. The antioxidative principle involves taking an electron from antioxidants at low $\mathrm{pH}$ which can be monitored by measuring the change in absorbance at $593 \mathrm{~nm}$, reducing ferric tripyridyl triazine (Fe III TPTZ) complex to ferrous form (which has an intense blue color) (Bordbar et al., 2013). Meanwhile, ABTS $^{\cdot+}$ radical scavenging activity is exclusively measured by the ability of an antioxidant compound involved in a hydrogen atom transfer, neutralizing generated $\mathrm{ABTS}^{-+}$(Olagunju et al., 2018).

This study concentrates on (i) analyzing the chemical composition of the $\mathrm{BCB}$ and (ii) investigating the effects of hydrolysis condition on antioxidant activity measured by $\mathrm{ABTS}^{\cdot+}$ radical scavenging activity and FRAP assay of the BCB proteolysate.

\section{MATERIALS AND METHODS}

\subsection{Materials}

\subsubsection{Baby clams}

Baby clams used in this study were purchased from a local market in Ho Chi Minh City, Vietnam. They were transported on ice to the laboratory of Ho Chi Minh City University of Technology - Vietnam National University Ho Chi Minh City within 4 hours, packed in polyethylene bags, labeled and stored $20^{\circ} \mathrm{C}$ until used.

\subsubsection{Enzyme preparations and chemicals}

Protease preparations including Alcalase ${ }^{\circledR} 2.5 \mathrm{~L}$, Protamex ${ }^{\circledR}$ and Flavourzyme ${ }^{\circledR}$ 500MG with their optimal working conditions being listed in Table 1 were obtained from Novozymes (Denmark) and $A B$ enzymes (Germany). Chemicals were provided by Sigma-Aldrich and Merck. Analytic quality of all reagents was required. Tests were performed with double-distilled water.
Table 1. Working condition of enzyme preparations

\begin{tabular}{lrr}
\hline $\begin{array}{l}\text { Enzyme } \\
\text { preparation }\end{array}$ & Optimal pH & $\begin{array}{r}\text { Optimal } \\
\text { temperature }\end{array}$ \\
\hline Alcalase & 7.5 & $55^{\circ} \mathrm{C}$ \\
Protamex & 6.5 & $55^{\circ} \mathrm{C}$ \\
Flavourzyme & 7 & $50^{\circ} \mathrm{C}$ \\
\hline
\end{tabular}

\subsection{Methods}

\subsubsection{Preparation of $B C B$}

BCB was obtained using the method of Zeng et al. (2014). After adding whole baby clams (200 g) to tap water in a 1:1 (w/v) ratio, the mixture was boiled for $40 \mathrm{~min}$. Then, $140 \mathrm{ml}$ of BCB was gained by filtration and vacuum evaporation with the rotating rate of $40-50 \mathrm{rpm}$.

\subsubsection{Determination of chemical composition of $B C B$}

Chemical composition of $\mathrm{BCB}$ including moisture content, ash content, soluble protein and crude lipid content were determined using air oven method $\left(100^{\circ} \mathrm{C}\right.$ for $5 \mathrm{~h}$; Association of Official Agricultural Chemists (AOAC) number 950.46B), basic heating technique $\left(550^{\circ} \mathrm{C}\right.$ for $5 \mathrm{~h}$; AOAC number 920.15$)$ (AOAC, 2000), method of Lowry et al. (1951), and method of Folch et al. (1957), respectively.

\subsubsection{Preparation of $B C B$ proteolysate}

The procedure of Vo et al. (2019) was slightly modified to prepare BCB hydrolysates. Prior to the addition of desired enzyme, $1 \mathrm{M} \mathrm{NaOH}$ or $\mathrm{HCl}$ solution was used to control the $\mathrm{pH}$ value of the mixture. After hydrolysis at a predetermined time, the enzymes were inactivated by heating the hydrolysates for 15 min at $90^{\circ} \mathrm{C}$, followed by centrifugation to recover the supernatant. The protein content of the proteolysate was determined employing the method of Lowry et al. (1951). The collected supernatants were frozen - dried using a freeze - dryer (Alpha 12/Ldplus, UK) and stored at $-20^{\circ} \mathrm{C}$ until being used.

\subsubsection{Effect of hydrolysis condition on the antioxidant activity of the proteolysate}

A single factor test approach, where one factor was altered on various levels while others being given, was employed to assess the impacts of five effective parameters consisting of hydrolysis enzyme type, $\mathrm{pH}$, temperature, $\mathrm{E}: \mathrm{S}$ ratio and hydrolysis time on the CBC of the WLSH proteolysate. The levels of hydrolysis parameters were shown in Table 2. 


\subsubsection{FRAP assay}

Method of Bordbar et al. (2013) with slight modification was used to determine the ferric reducing capacity of hydrolysates. According to this method, by the action of electron-donating antioxidants, a colorless ferric-2,4,6-Tris(2-pyridyl)-s-triazine complex $\left(\mathrm{Fe}^{3+}-\mathrm{TPTZ}\right)$ is reduced to a blue-colored ferrous complex $\left(\mathrm{Fe}^{2+}-\mathrm{TPTZ}\right)$ at low $\mathrm{pH}$. The reduction is monitored by measuring the change of absorbance at $593 \mathrm{~nm}$. The Trolox standard with the purity of 97\% from Sigma-Aldrich company was used in this study and its absorbance was plotted as a function of its concentrations for the standard reference data.

\subsubsection{ABTS $^{++}$radical scavenging activity assay}

$\mathrm{ABTS}^{\cdot+}$ radical scavenging activity of the proteolysate was determined employing the method of Re et al. (1999). The $\mathrm{ABTS}^{\cdot+}$ solution containing $7 \mathrm{mM}$ of ABTS and $2.45 \mathrm{mM}$ sodium persulfate was diluted in phosphate buffer $(5 \mathrm{mM}, \mathrm{pH} 7.4)$ to an absorbance of $0.7 \pm 0.02$ at $734 \mathrm{~nm}$. $20 \mu \mathrm{L}$ of the proteolysate $(5 \mathrm{mg} / \mathrm{ml})$ was added to $2 \mathrm{~mL}$ of $\mathrm{ABTS}^{\cdot+}$ solution, then after $6 \mathrm{~min}$, the absorbance reading was taken at $30^{\circ} \mathrm{C}$. Trolox with the purity of $97 \%$ from Sigma-Aldrich company was used as standard and its absorbance was plotted as a function of its concentration for the standard reference data.

Table 2. Levels of hydrolysis condition parameters

\begin{tabular}{lcccrr}
\hline Test & Earameter & Enzyme type & $\begin{array}{c}\text { Temperature } \\
\left({ }^{\mathbf{a}} \mathbf{C}\right)\end{array}$ & $\begin{array}{r}\text { E:S ratio } \\
(\mathbf{U} / \mathbf{g} \text { protein) }\end{array}$ & $\begin{array}{r}\text { Hydrolysis } \\
\text { time (min) }\end{array}$ \\
\hline Enzyme type & $\begin{array}{c}\text { 3 enzyme preparations } \\
\text { (Table 1) }\end{array}$ & $\begin{array}{c}\text { Optimal } \\
(\text { Table 1) }\end{array}$ & $\begin{array}{c}\text { Optimal } \\
(\text { Table 1) }\end{array}$ & $7.5^{\mathrm{b}}$ & $100^{\mathrm{b}}$ \\
$\mathrm{pH}$ & Flavourzyme $^{\mathrm{a}}$ & $5-7$ & $\begin{array}{c}\text { Optimal } \\
(\text { Table 1) }\end{array}$ & $7.5^{\mathrm{b}}$ & $100^{\mathrm{b}}$ \\
Temperature & Flavourzyme $^{\mathrm{a}}$ & $7^{\mathrm{a}}$ & $40-60$ & $7.5^{\mathrm{b}}$ & $100^{\mathrm{b}}$ \\
E:S ratio & Flavourzyme $^{\mathrm{a}}$ & $7^{\mathrm{a}}$ & $50^{\mathrm{a}}$ & $2.5-12.5$ & $100^{\mathrm{b}}$ \\
Hydrolysis time & Flavourzyme $^{\mathrm{a}}$ & $7^{\mathrm{a}}$ & $50^{\mathrm{a}}$ & $5^{\mathrm{a}}$ & $30-200$ \\
\hline
\end{tabular}

a: chosen hydrolysis parameter after each investigation

\section{b: set hydrolysis parameter}

\subsubsection{Statistical analysis}

Data were presented as means \pm standard deviations of triplicate determinations. Analysis of variance (one-way ANOVA) was performed on the data, and the significance was determined using Tukey method $(\mathrm{P}<0.05)$. These analyses were performed using the Statgraphics Centurion 18 software Statgraphics Technologies Inc. (https://www.statgraphics.com/centurion-xviii).

\section{RESULTS AND DISCUSSION}

\subsection{Chemical composition of $\mathrm{BCB}$}

BCB composes of $97.55 \pm 0.89 \%$ moisture, $1.52 \pm 0.16 \%$ protein, $0.09 \pm 0.02 \%$ crude lipid and

Table 3. Antioxidant activity of BCB, vitamin C and BHT

\begin{tabular}{lrrr}
\hline Method & BCB & Vitamin C & BHT \\
\hline ABTS $^{\bullet+}$ scavenging activity $(\mu \mathrm{M} \mathrm{TE})$ & $328.22 \pm 17.78$ & $5481.27 \pm 4.45$ & $1969.32 \pm 5.02$ \\
FRAP value $(\mu \mathrm{M}$ TE) & $126.66 \pm 6.58$ & $2862.52 \pm 2.78$ & $987.95 \pm 4.45$ \\
\hline
\end{tabular}

\subsection{Effect of enzyme type on antioxidant activity of BCB proteolysate}

In this study, Flavourzyme proteolysate showed the highest antioxidant capacity with $\mathrm{ABTS}^{\bullet+}$ scavenging activity and FRAP value of $697.33 \pm 31.68 \mu \mathrm{M}$
$0.37 \pm 0.04 \%$ ash. In the study of Tsai et al. (2006), baby clam broth was used to obtain bioactive proteolysate, of which the protein content was 1.8 lower than that the BCB. Additionally, the BCB expressed $\mathrm{ABTS}^{\bullet+}$ scavenging activity of $328.22 \pm 17.78 \mu \mathrm{M}$ TE (16.7 and 6.0 times lower than those of vitamin $\mathrm{C}$ and BHT, respectively), FRAP value of $126.66 \pm 6.58 \mu \mathrm{M}$ TE (22.6 and 7.8 folds lower than those of vitamin $\mathrm{C}$ and BHT, in order) (Table 3). Therefore, the $\mathrm{BCB}$ was considered as a potential source for producing antioxidant proteolysate.
TE and $212.21 \pm 6.84 \mu \mathrm{M}$ TE, respectively, followed by Protamex and Alcalase hydrolysate (Fig. 1). It could be due to the fact that Flavourzyme preparation, containing both endo- and exo-peptidases, released more antioxidant peptides as it had a broad 
substrate specificity (Castro \& Sato, 2015). Flavourzyme was also proven to have the most potential to obtain the proteolysate possessing the highest antioxidant capacity from round scad muscle
(Thiansilakul et al., 2006), Acetes japonicus (Vo, 2018) and whiteleg shrimp head (Vo et al., 2019). Hence, Flavourzyme was used for further experiments.

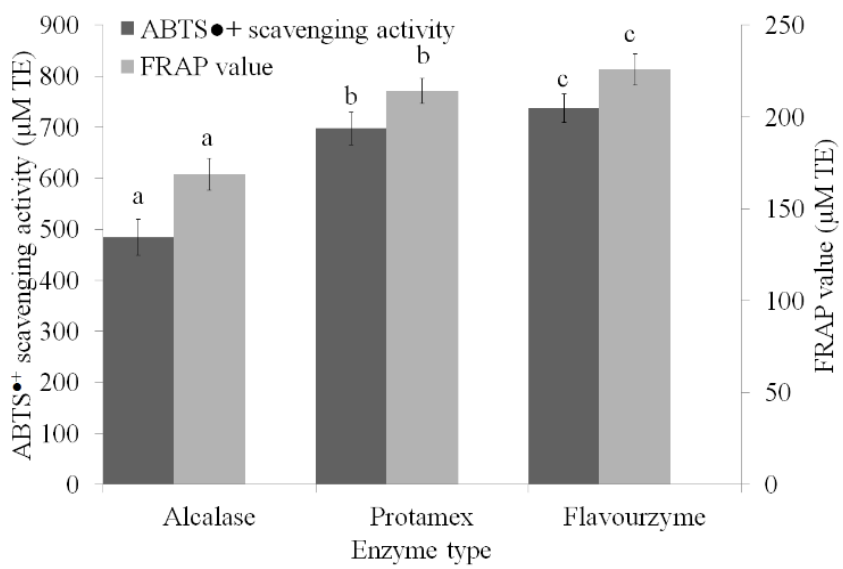

Fig. 1. Effect of enzyme type on the antioxidant activity of BCB proteolysate

The same bars with different letters indicate significant differences $(P<0.05)$

\subsection{Effect of $\mathbf{p H}$ on antioxidant activity of BCB proteolysate}

The study showed that at optimal working $\mathrm{pH}$ range of Flavourzyme (5-7), at $\mathrm{pH}$ 7, both $\mathrm{ABTS}^{\bullet+}$ scavenging activity and FRAP value reached the highest values of $757.33 \pm 38.33 \mu \mathrm{M} \mathrm{TE}$ and $236.32 \pm 4.74$ $\mu \mathrm{M}$ TE, respectively (Fig. 2). It may be because the environmental $\mathrm{pH}$ had a significant impact on the ionization ability of substrate and enzyme via changing their charge distribution and conformation, affecting catalytic activity of enzyme and antioxidant activity of proteolysate (Shu et al., 2017). The antioxidant potential of proteolysate is dependent on its amino acid composition and sequence of peptides present in it. The amount of generated antioxidant peptides was reduced at non-optimal $\mathrm{pH}$ as catalytic activity of enzyme was decreased. Therefore, $\mathrm{pH} 7$ was selected for further experiments.

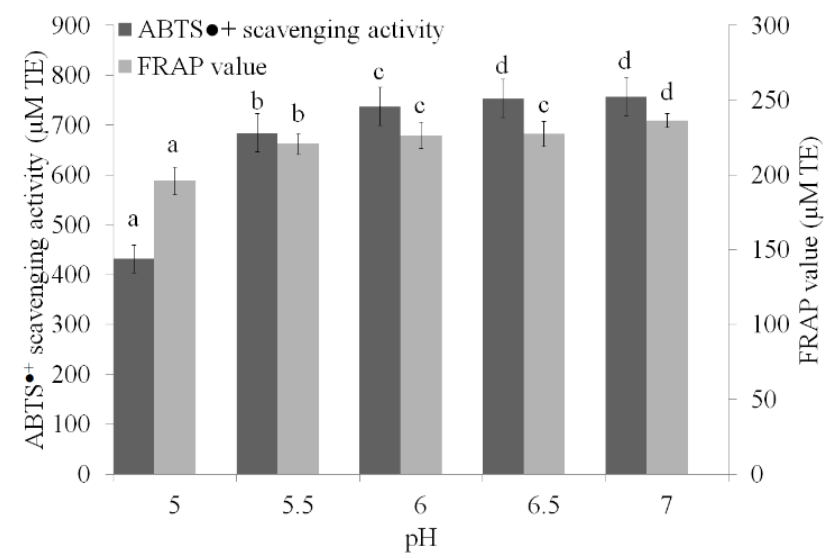

Fig. 2. Effect of $\mathbf{p H}$ on the antioxidant activity of $\mathrm{BCB}$ proteolysate

The same bars with different letters indicate significant differences $(P<0.05)$

\subsection{Effect of temperature on antioxidant activity of $\mathrm{BCB}$ proteolysate}

As illustrated in Fig. 3, as temperature increased both $\mathrm{ABTS}^{\bullet+}$ scavenging activity and FRAP value of the $\mathrm{BCB}$ proteolysate augmented and reached the peaks of $767.33 \pm 38.33 \mu \mathrm{M}$ TE and $232.89 \pm 7.63 \mu \mathrm{M}$ $\mathrm{TE}$ at hydrolysis temperature of $50^{\circ} \mathrm{C}$, respectively. The antioxidant activity of the proteolysate was enhanced as temperature changed the conformation of 
substrate and enzyme, exposing the hydrophobic or hydrogen-donating amino acid buried inside the protein (Ren et al., 2008). On the other hand, the contact between enzyme and substrate molecules was limited at non-optimal temperature through de- creasing the movement of these molecules or changing the configuration of enzyme and substrate, lowering the formation of antioxidant peptides. Ren et al. (2008) and Vo et al. (2019) also reported the same result. Therefore, the hydrolysis temperature of $50^{\circ} \mathrm{C}$ was employed for further studies.

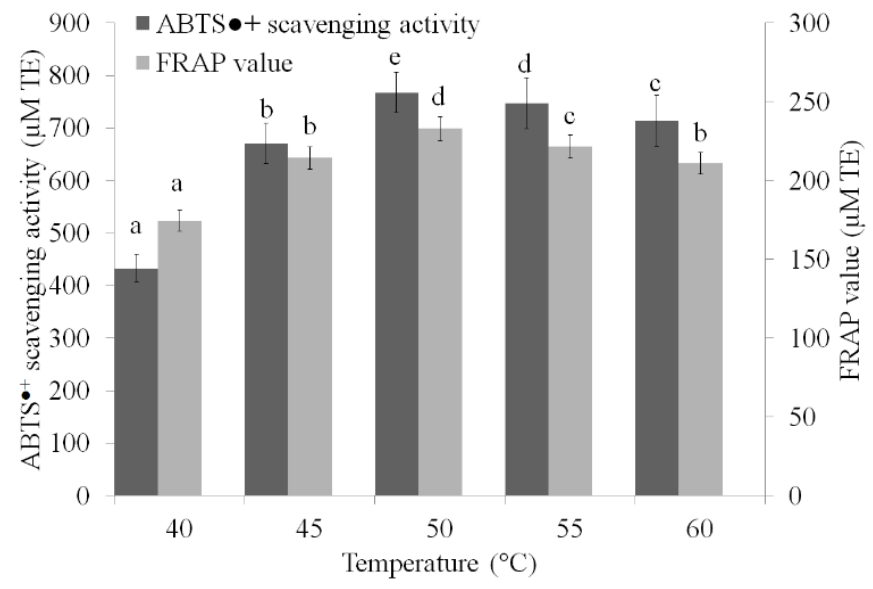

Fig. 3. Effect of temperature on the antioxidant activity of BCB proteolysate. The same bars with different letters indicate significant differences $(P<0.05)$

\subsection{Effect of $E: S$ ratio on antioxidant activity of $\mathrm{BCB}$ proteolysate}

Fig. 4 described the E:S ratio - antioxidant activity profile, showing that at the $\mathrm{E}: \mathrm{S}$ ratio of $5 \mathrm{U} / \mathrm{g}$ protein both $\mathrm{ABTS}^{\bullet+}$ scavenging activity and FRAP value of the proteolysate peaked at $767.33 \pm 38.33 \mu \mathrm{M}$ TE and $239.21 \pm 7.21 \mu \mathrm{M} \mathrm{TE}$, respectively. While the adequate amount of enzyme for substrate enhanced the recovery yield of proteolysate with high antioxidant activity, lower or higher enzyme amount may lower the antioxidant capacity of the proteolysate due to the excess or lack of substrate for the hydrolysis reaction. Similar observation was also found in previous studies of Gunasekaran et al. (2015) and Vo (2018). Ergo, the E:S ratio of $5 \mathrm{U} / \mathrm{g}$ protein was selected for further analysis.

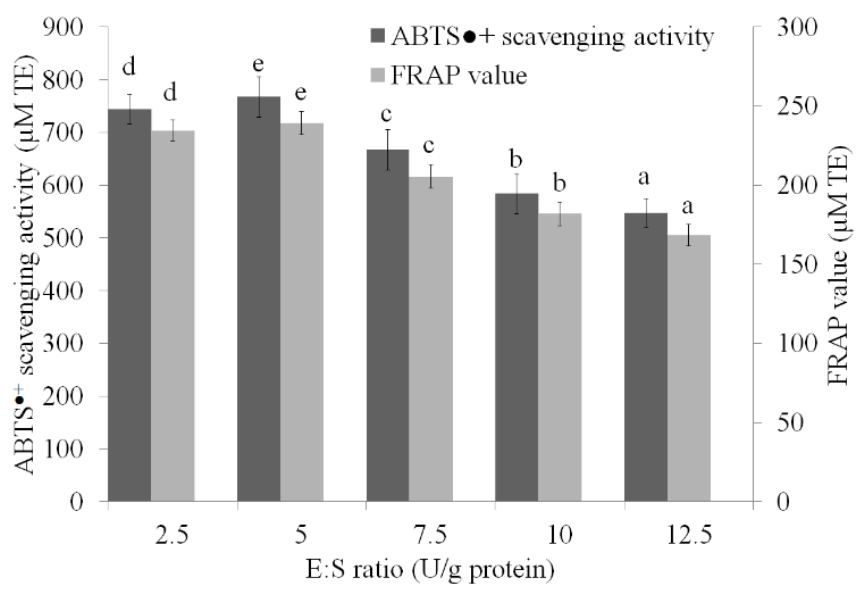

Fig. 4. Effect of E:S ratio on the antioxidant activity of $B C B$ proteolysate. The same bars with different letters indicate significant differences $(\mathbf{P}<0.05)$ 


\subsection{Effect of hydrolysis time on antioxidant activity of $\mathrm{BCB}$ proteolysate}

As can be seen in the Fig. 5, at the hydrolysis time of $50 \mathrm{~min}$, the $\mathrm{ABTS}^{\bullet+}$ scavenging activity and FRAP value of the proteolysate reached the highest points of $770.67 \pm 28.33 \mu \mathrm{M}$ TE and $245.26 \pm 7.37$ $\mu \mathrm{M}$ TE, respectively. However, longer hydrolysis could lower the antioxidant capacity of proteolysate by causing deeper cleavage of the enzyme on generated peptides or reducing the enzyme catalytic activity. This observation was in accordance with the findings of Bordbar et al. (2013) and Vo (2018). For this reason, the hydrolysis time of 50 min was chosen for further experiments.

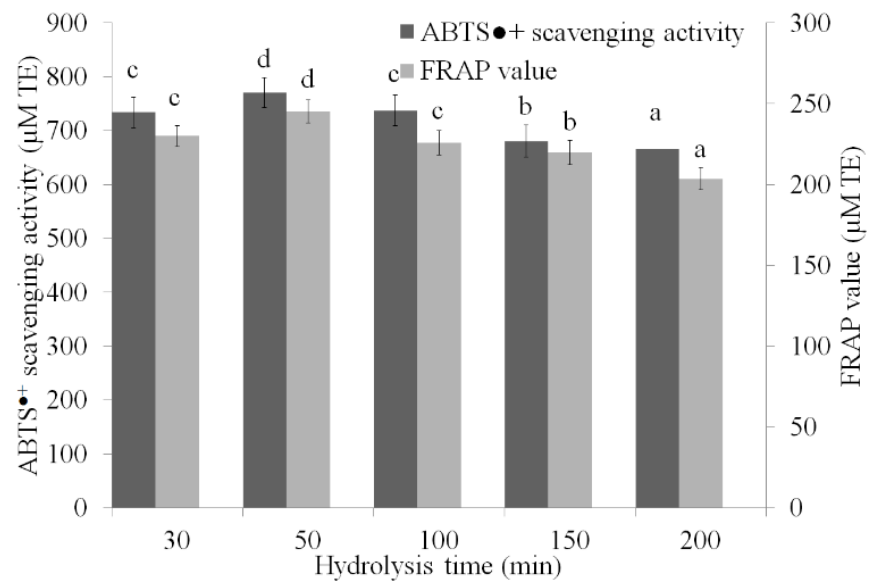

Fig. 5. Effect of hydrolysis time on the antioxidant activity of BCB proteolysate. The same bars with different letters indicate significant differences $(\mathbf{P}<0.05)$

\section{CONCLUSIONS}

This study revealed that the antioxidant activity of the BCB proteolysate was significantly affected by hydrolysis condition including protease type, $\mathrm{pH}$, temperature, $\mathrm{E}: \mathrm{S}$ ratio and hydrolysis time. It is also suggested that the BCB could be taken into consideration as a promising source of antioxidant peptides or protein hydrolysates, not only adding the value for the underutilized by-product but also minimizing its negative impact on the environment. Nevertheless, in vivo experiments on antioxidant mechanism and activity should be done for further utilization of this by-product.

\section{REFERENCES}

AOAC. (2000). Official Methods of Analysis of the Association of Official Analytical Chemists. The association of official analytical chemists.

Bordbar, S., Ebrahimpour, A., Hamid, A. A., Manap, M. Y. A., Anwar, F., \& Saari, N. (2013). The Improvement of The Endogenous Antioxidant Property of Stone Fish (Actinopyga lecanora) Tissue Using Enzymatic Proteolysis. BioMed Research International, 2013, 1-9. https://doi.org/10.1155/2013/849529.

Castro, R. J. S. d., \& Sato, H. H. (2015). A response surface approach on optimization of hydrolysis parameters for the production of egg white protein hydrolysates with antioxidant activities. Biocatalysis and
Agricultural Biotechnology, 4, 55-62.

https://doi.org/10.1016/j.bcab.2014.07.001.

Folch, J., Lees, M., \& Stanley, G. H. S. (1957). A simple method for the isolation and purification of total lipides from animal tissues. The Journal of Biological Chemistry, 226(1), 497-509.

Gunasekaran, J., Kannuchamy, N., Kannaiyan, S., Chakraborti, R., \& Gudipatti, V. (2015). Protein Hydrolysates from Shrimp (Metapenaeus dobsoni) Head Waste: Optimization of Extraction Conditions by Response Surface Methodology. Journal of Aquatic Food Product Technology, 24(5), 429-442. https://doi.org/10.1080/10498850.2013.787134.

Kim, S.-K., \& Wijesekara, I. (2010). Development and biological activities of marine-derived bioactive peptides: A review. Journal of Functional Foods, 2(1), 1-9. https://doi.org/10.1016/j.jff.2010.01.003.

Lowry, O. H., Rosebrough, N. J., Farr, A. L., \& Randall, R. J. (1951). Protein measurement with the Folin phenol reagent. Journal of Biological Chemistry, 193(1), 265-275.

Olagunju, A. I., Omoba, O. S., Enujiugha, V. N., Alashi, A. M., \& Aluko, R. E. (2018). Pigeon pea enzymatic protein hydrolysates and ultrafiltration peptide fractions as potential sources of antioxidant peptides: An in vitro study. LWT - Food Science and Technology, 97, 269-278. https://doi.org/10.1016/j.lwt.2018.07.003. 
Re, R., Pellegrini, N., Proteggente, A., Pannala, A., Yang, M., \& Rice-Evans, C. (1999). Antioxidant activity applying an improved ABTS radical cation decolorization assay. Free Radical Biology \& Medicine, 26(9-10), 1231-1237. https://doi.org/10.1016/s0891-5849(98)00315-3.

Ren, J., Zhao, M., Shi, J., Wang, J., Jiang, Y., Cui, C., Kakuda, Y., \& Xue, S. J. (2008). Optimization of antioxidant peptide production from grass carp sarcoplasmic protein using response surface methodology. LWT - Food Science and Technology, 41, 16241632. https://doi.org/10.1016/j.lwt.2007.11.005.

Sarmadi, B. H., \& Ismail, A. (2010). Antioxidative peptides from food proteins: A review. Peptides, 31(10), 1949-1956. https://doi.org/10.1016/j.peptides.2010.06.020.

Shu, G., Zhang, B., Zhang, Q., Wan, H., \& Li, H. (2017). Effect of Temperature, pH, Enzyme to Substrate Ratio, Substrate Concentration and Time on the Antioxidative Activity of Hydrolysates from Goat Milk Casein by Alcalase. Acta Universitatis Cibiniensis. Series E: Food Technology, 20(2), 29-38. https://doi.org/10.1515/aucft-2016-0013.

Thiansilakul, Y., Benjakul, S., \& Shahidi, F. (2006). Antioxidative Activity of Protein Hydrolysate from Round Scad Muscle Using Alcalase and Flavourzyme. Journal of Food Biochemistry, 31(2), 266-287. https://doi.org/10.1111/j.17454514.2007.00111.x.

Tsai, J. S., Lin, T. C., Chen, J. L., \& Pan, B. S. (2006) The inhibitory effects of freshwater clam (Corbicula fluminea, Muller) muscle protein hydrolysates on angiotensin I converting enzyme. Process Biochemistry, 41(11), 2276-2281. https://doi.org/10.1016/j.procbio.2006.05.023.
Vo, T. D. L. (2018). Investigation of antioxidant activity of proteolysate derived from Acetes japonicus. Journal of science and Technology (JST-UD), 11(132), 137-141.

Vo, T. D. L., Bui, A. N. N., Nguyen, T. V. V., Nguyen, N. N. P., \& Dang, H. V. (2019). Investigation into antioxidant activity of protein hydrolysate derived from white leg shrimp head (Litopenaeus vannamei). Journal of science and Technology (JST-UD), 17(1.2), 75-79.

Wang, L. S., Huang, J. C., Chen, Y. L., Huang, M., \& Zhou, G. H. (2015). Identification and Characterization of Antioxidant Peptides from Enzymatic Hydrolysates of Duck Meat. Journal of Agricultural and Food Chemistry, 63(13), 3437-3444. https://doi.org/10.1021/jf506120w.

Zeng, Y., Guan, Y., Han, W., \& Sun, Y. (2014). Antioxidant peptides from freshwater clam extract using enzymatic hydrolysis. African Journal of Food Science, 8(3), 148-154. 10.5897/AJFS2013.1027.

Zhang, Y., Duan, X., \& Zhuang, Y. (2012). Purification and characterization of novel antioxidant peptides from enzymatic hydrolysates of tilapia (Oreochromis niloticus) skin gelatin. Peptides, 38(1), 13-21. https://doi.org/10.1016/j.peptides.2012.08.014. 